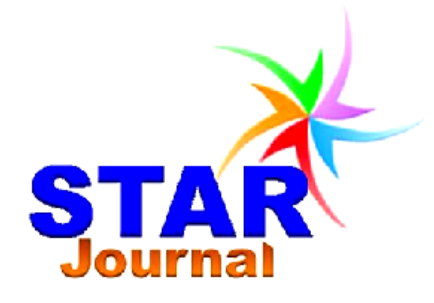

ISSN: 2226-7522(Print) and 2305-3327(Online) Science, Technology and Arts Research Journal

Oct-Dec 2012, 1(4):33-37 www.starjournal.org

Copyright $\odot 2012$ STAR. All Rights Reserved

Original Research

\title{
Microbiological Quality of Drinking Water Sources in Rural Communities of Dire Dawa Administrative Council
}

\author{
Desalegn Amenu*, Sissay Menkir and Tesfaye Gobena \\ College of Natural and Computational Science, Wollega University, PO Box: 395, Nekemte, Ethiopia
}

\begin{tabular}{|c|c|}
\hline Abstract & \\
\hline \multirow{9}{*}{$\begin{array}{l}\text { In Ethiopia, access to improved water supply and sanitation was estimated at } 38 \% \\
\text { and } 12 \% \text { respectively. Three- forth of the health problems of children in Ethiopia are } \\
\text { communicable diseases due to polluted water and improper water handling } \\
\text { practices. Thus, this study was conducted to assess the microbiological quality of } \\
\text { drinking water sources in rural communities of Dire Dawa Administrative Council } \\
\text { (Adada Peasant Association). A cross-sectional study was conducted from February } \\
2011 \text { to May } 2011 \text {. Microbiological water quality parameters were analyzed using } \\
\text { the membrane filtration method. Water analysis demonstrated that all water sources } \\
\text { in the study area were contaminated with total coliforms and fecal coliform. The fact } \\
\text { that, about } 83.34 \% \text { of the water sample was positive for indicator bacteria shown } \\
\text { that the three selected Peasant Associations had risk of contamination. High } \\
\text { concentration of microbiological indicators in all water sources of this study area } \\
\text { have demonstrated the presence of pathogenic organisms which constitute a threat } \\
\text { to anyone consuming or in contact with these waters. The majority of the drinking } \\
\text { water sources is either of unacceptable quality or grossly polluted. Regular quality } \\
\text { control mechanisms need to be in place to ensure safety of drinking water. }\end{array}$} & $\begin{array}{ll}\text { Received } & : 30-10-2012 \\
\text { Revised } & : 21-12-2012 \\
\text { Accepted } & : 23-12-2012\end{array}$ \\
\hline & Keywords: \\
\hline & Escherichia coli \\
\hline & Total Coliform \\
\hline & Fecal Coliform \\
\hline & Dire Dawa \\
\hline & ${ }^{*}$ Corresponding Author: \\
\hline & Desalegn Amenu \\
\hline & \\
\hline
\end{tabular}

\section{INTRODUCTION}

High incidence of childhood diarrhea, helminthiasis, trachoma and the overall high mortality rates are associated with poor environmental sanitation (Mengesha et al., 2004). The World Health Organization estimated that up to $80 \%$ of all sicknesses and diseases in the world is caused by inadequate sanitation, polluted water or unavailability of water. In Ethiopia over $60 \%$ of the communicable diseases are due to poor environmental health conditions arising from unsafe and inadequate water supply and poor hygienic and sanitation practices (WHO, 2004).

Several studies have confirmed that waterrelated diseases not only remain a leading cause of morbidity and mortality worldwide but that the spectrum of diseases is expanding and the incidence of many water-related microbial disease is increasing (WHO, 2003). Diarrhea remains a major killer in children and it is estimated that $80 \%$ of all illness in developing countries is related to water and sanitation; and that $15 \%$ of all child deaths under the age of 5 years in developing countries results from diarrheal diseases (WHO, 2003). In rural areas and villages of Ethiopia, water for human consumption, drinking, washing (bathing, laundry), for preparation of food etc, is obtained from rivers, streams, shallow wells, springs, lakes, ponds, and rainfall. Unless water is made safe or treated for human consumption, it may be hazardous to health and transmit diseases. The main contaminants of these water sources are human excreta, animal waste and effluent because of open field defecation practices. Thus, the majority of rural communities use water from contaminated or doubtful sources, which expose the people to various water-borne diseases (FDRE, MoWR, 2004). 
Desalegn Amenu, Sissay Menkir \& Tesfaye Gobena

Bacteriological techniques employed to distinguish between human and animal fecal pollution are a valuable tool in water pollution control programs, because they are useful in tracing the source of pollution of drinking water supplies, and they can help in assessing the overall adequacy of protection rendered to small rural water supplies (Mara and Oragui,1985). Fresh addition of human fecal material can be distinguished from additions of animal feces in environmental waters by the ratio of fecal coliforms to fecal streptococci (FC/FS).

WHO bacteriological guidelines WHO (2004) and Federal Democratic Republic of Ethiopia, Ministry of Water Resources (2002) for drinking water recommend zero total coliforms and fecal streptococci/100 $\mathrm{ml}$ of water. Therefore, this study evaluates the two indicators of drinking water quality (total coliform and fecal coliform) from different water sources determines the microbiological quality of drinking water sources at Dire Dawa Rural Community.

In Ethiopia water is inadequate, 3-4 lit/capita /day, and distance traveled to fetch water is 3-8 km (IWSC, 1989). Regular examination of water quality for the presence of organisms, chemicals, and other physical contents provides information on the level of the safety of water. Frequent examinations of fecal indicator organisms remain the most sensitive way of assessing the hygienic conditions of water. Indicator organisms of faecal pollution include the coliform group as a whole and particularly Escherichia coli, streptococcus feacalis and some thermo tolerant organisms such as clostridium perfringens (WHO.2004). The overall concepts adopted for microbiological quality is that no water intended for human consumption shall contain $\mathrm{E}$ coli in $100 \mathrm{ml}$ sample. Treated water entering the distribution system should be 0 faecal coliforms and 0 coliform organisms per $100 \mathrm{ml}$ of water. This study was conducted to assess the microbiological quality of drinking water sources and investigate the possible sources of contamination.

\section{MATERIALS AND METHODS}

A cross-sectional and analytical study was conducted to assess the microbiological quality of water sources in rural communities of Dire Dawa Administrative Council. Totally, 90 water samples were collected from unprotected and protected spring, unprotected and protected well (hand pump) and tap water. The sampling strategy was based on capturing all types of water sources used by the community. Since some types of
Sci. Technol. Arts Res. J., Oct-Dec 2012, 1(4):33-37

water sources, like unprotected wells in rural area and unprotected springs, protected spring and well also from tap water in urban areas are very few in numbers we took equal number of samples from each type of water sources. Water samples were collected at the randomly selected urban and rural areas of the Dire Dawa Administrative Council. The set of water samples taken were as follows: 18 samples from protected springs; 18 samples from protected wells; 18 samples from unprotected springs; 18 samples from unprotected well; and 18 samples from tap water.

The method of water sample collection at each source was according to the WHO Guidelines for Drinking water quality assessment (WHO, 2004). The collected water samples from each source was labeled and kept in icebox during transportation and analyzed in the laboratory. Samples were analyzed using standardized bacteriological methods for water quality analysis (Cheesbrough, 1987) to determine the degree of contamination. All Samples were analyzed for total coliform count and fecal coliform in Dire Dawa Water Supply and Authority treatment Laboratory. Moreover, to keep the validity of the analysis, as a control, randomly selected samples, one from each source, were taken to Haramaya University General Microbiology Laboratory and analyzed following the same procedure.

The result was interpreted using $\mathrm{WHO}$ Guidelines for drinking water (WHO, 2004). Checklist was prepared to get specific information to be answered by one of the elder persons in the study area. This is to associate the extent of contamination of water sources, constructing organization (if protected) and willingness to protect (if unprotected). Constructional and relevant sanitary aspects of observations were also carried out while the sample collector collected samples at each site.

Samples for microbial indicators(TC, FC, were analyzed by $100 \mathrm{ml}$ membrane filtration technique, using $0.47 \mathrm{~mm}$ diameter, $0.45 \mu \mathrm{m}$ pore size filters (Gelman Sciences sterilized membrane) as specified in standard methods (APHA, 1998). For TC, the 100ml filtration technique was used with membrane Lauryl Sulfate (MLS) broth incubated at $37{ }^{\circ} \mathrm{C}$ for $24 \mathrm{hr}$.; and Yellow colonies were counted as TC. Similarly, for FC the $100 \mathrm{ml}$ filtration technique also was used with membrane Lauryl Sulfate (MLS) broth incubated at $44.5^{\circ} \mathrm{C}$ for $24 \mathrm{hr}$.; Yellow colonies were counted as FC. 
Desalegn Amenu, Sissay Menkir \& Tesfaye Gobena

The samples were analyzed for total coliform (TC) and faecal coliforms (FC) using the membrane filter technique as outlined by the APHA (1998). This technique involved filtering water through a membrane that retained total coliforms, fecal coliforms, incubating this membrane on a growth promoting medium and then counting the resultant TC and FC units.

\section{RESULTS}

Ninety water samples were taken from the five types of water sources (unprotected wells, unprotected springs, protected wells, protected springs and tap water). Analysis of unprotected springs and wells demonstrated that $100 \%$, of the samples had all kind of indicator bacteria. 100\% of the positive samples had total and fecal coliforms, of these $35.7 \%$ had E. coli. Eight five of protected wells and springs had all kinds of indicator bacteria. Moreover, the same proportion
Sci. Technol. Arts Res. J., Oct-Dec 2012, 1(4):33-37

$(85 \%)$ of the samples had both total and fecal coliform. On the other hand, analysis of water line (tap water) demonstrated that $50 \%$ of the samples had indictor bacteria, $33.34 \%$ fecal coliform and E.coli (Table1 and 2).

The result of microbiological water quality parameters of each sources were compared with WHO, (2004) standard. Bacteriological analysis of samples from the five sources (protected spring, unprotected spring, protected well, unprotected well and tap water) Dire Dawa Rural Communities showed that all samples sources from each sites (Adada) were positive for total coliforms and fecal coliform in two rounds of triplicate sampling. Indicator bacteria were often encountered in all samples from water sources of the study area. Less frequent occurrence of indicators was observed at samples from the tap water (Table1, 2 and 3).

Table1: Bacteriological analysis of unprotected well, unprotected springs and tap water in Dire Dawa Rural Communities between February 2011 and May, $(n=6)$.

\begin{tabular}{cccccccc}
\hline \multirow{2}{*}{ Sites } & \multirow{2}{*}{$\begin{array}{c}\text { Type of } \\
\text { Organism }\end{array}$} & \multicolumn{2}{c}{$\begin{array}{c}\text { Unprotected } \\
\text { well }\end{array}$} & \multicolumn{2}{c}{$\begin{array}{c}\text { Unprotected } \\
\text { spring }\end{array}$} & \multicolumn{2}{c}{ Tap water } \\
\cline { 3 - 8 } & & F & $\%$ & F & $\%$ & F & $\%$ \\
\hline \multirow{2}{*}{ Adada } & Total Coliform & 6 & 100 & 6 & 100 & 3 & 50 \\
& Fecal Coliform & 6 & 100 & 6 & 100 & 2 & 33.34 \\
\hline
\end{tabular}

Table 2: Bacteriological analysis of protected well and protected springs in Dire Dawa Rural Communities between February 2011 and May, $(n=6)$.

\begin{tabular}{cccccc}
\hline \multirow{2}{*}{ Sites } & \multirow{2}{*}{ Type of Organism } & \multicolumn{2}{c}{ Protected Well } & \multicolumn{2}{c}{ Protected Spring } \\
\cline { 3 - 6 } & & $\begin{array}{c}\text { Positive } \\
\text { Samples }\end{array}$ & $\%$ & $\begin{array}{c}\text { Positive } \\
\text { samples }\end{array}$ & $\%$ \\
\hline \multirow{2}{*}{ Adada } & Total Coliform & 5 & 83.34 & 5 & 83.34 \\
& Fecal Coliform & 5 & 83.34 & 4 & 66.67 \\
\hline
\end{tabular}

Table 3: Occurrence of indicator bacteria and Mean bacteriological counts $(100 / \mathrm{ml})$ of five types of water sources in Dire Dawa communities during February and May 2011.

\begin{tabular}{|c|c|c|c|c|c|c|}
\hline \multirow{2}{*}{ Sites } & \multirow{2}{*}{ Water sources } & \multicolumn{3}{|c|}{$\begin{array}{c}\text { Occurrences of Indicator } \\
\text { Organisms }\end{array}$} & \multicolumn{2}{|c|}{$\begin{array}{c}\text { Mean Bacteriological } \\
\text { Count }\end{array}$} \\
\hline & & $\begin{array}{l}\text { Positive } \\
\text { Samples }\end{array}$ & $\begin{array}{c}\text { Total } \\
\text { Coliform }\end{array}$ & $\begin{array}{c}\text { Fecal } \\
\text { Coliform }\end{array}$ & $\begin{array}{c}\text { Total } \\
\text { Coliform }\end{array}$ & $\begin{array}{c}\text { Fecal } \\
\text { Coliform }\end{array}$ \\
\hline \multirow{5}{*}{ Adada } & Unprotected well & 6 & $6(100 \%)$ & $6(100 \%)$ & $81.34 \pm 08.07$ & $33.33 \pm 8.80$ \\
\hline & Unprotected spring & 6 & $6(100 \%)$ & $6(100 \%)$ & $64.50 \pm 08.61$ & $21.16 \pm 6.20$ \\
\hline & Protected well & 6 & $5(83.34 \%)$ & $5(83.34 \%)$ & $67.83 \pm 14.00$ & $18.00 \pm 7.68$ \\
\hline & Protected spring & 6 & $5(83.34 \%)$ & $4(66.67 \%)$ & $59.17 \pm 06.66$ & $15.34 \pm 6.59$ \\
\hline & household water & 6 & $3(50 \%)$ & $2(33.34 \%)$ & $01.50 \pm 00.71^{\mathrm{d}}$ & $00.34 \pm 0.20$ \\
\hline
\end{tabular}


Desalegn Amenu, Sissay Menkir \& Tesfaye Gobena

\section{DISCUSSION}

Fecal pollution of drinking water introduces a variety of intestinal pathogens (Mengesha et.al. 2004). The presence of indicator organisms calls a need for further survey, investigation and examination of drinking water sources. The site from where water is collected can be a source of disease. If the site is unprotected there is a risk that women and children collecting water from these sources will be infected. In this study the majority of the rural areas was using unprotected sources and some protected ones but not regularly disinfected and maintained. Observation showed that the unprotected wells mostly found in towns are constructed very near or down to latrines (WHO, 2006).

In the case of ground water, like protected springs, wells and protected water connection systems, it should be possible to achieve very low levels of contamination. However, the study result indicated that protected water sources are subjected for a high level of fecal contamination in almost all cases. Some of the protected water sources are said to be chlorinated though not regularly done. In regularly checked water sources the E.coli count should have been almost zero per $100 \mathrm{ml}$ (Cheesbrough, 1987). This fact is only observed in $6(14.3 \%)$ of the protected water sources.

A study conducted in Jimma also showed very high nitrate concentration in protected springs indicating the presence of organic pollution (Faaris, 1999). A similar study conducted in Uganda, in tropical slum areas, the predominant source for drinking water is protected springs. Nevertheless, tests carried out on these water sources revealed that it was unsafe for drinking mainly due to fecal contamination and hence the residents are exposed to a wide range of diseases.

One of the possible reasons might be constructional defects on casing, concrete covers, fences, diversion ditches, and protection of eye of springs and other plumbing accessories. Furthermore, lack of regular supervision, disinfection and proper maintenance might be the reasons for contaminating protected water sources (MOH, 1997). The high level of E.coli can also be explained by the fact that poor sanitation habit and hygiene education influences the use of protected water supplies. Study conducted in Bangladesh revealed that $95 \%$ of the urban population had access to safe drinking water and $35 \%$ of the population had access to sanitation. But data on the level of hygiene
Sci. Technol. Arts Res. J., Oct-Dec 2012, 1(4):33-37

education was much lower (IWSC, 1989). As a result health impact reduction in diarrhea was marginal.

In addition, analysis of 144 water and sanitation projects worldwide concludes that sanitation has great impact than water supply (IWSC, 1989). All water sources are grossly polluted. The type of coliform exhibited is a fecal type specifically of human origin. The effect, therefore, is attributed to constructional defects, poor sanitation, low level of hygiene education, poor supervision and maintenance and irregular disinfection.

According to Mengesha and his co-workers, research conducted in North Gonder, demonstrated that $50 \%$ of the samples had a coli form count of 180 and above $/ 100 \mathrm{ml}$ and the lowest coliform count was 13 coliform $/ 100 \mathrm{ml}$ (Mengesha et al., 2004), which is higher than the present study of Dire Dawa rural communities in which the highest total coliform 133.34 coliform $1100 \mathrm{ml}$ and the lowest total coliform 1.50 coliforms $/ 100 \mathrm{ml}$. In another study in South Wello, Ethiopia, Atnafu demonstrated that $75 \%$ of the samples from protected springs were contaminated with total coliforms (Atnafu, 2006). This was less than in the present study, where all water sources were contaminated with total coliform. And also the as research conducted in Yubdo-Legebatu by Birhanu(2008) indicated that all the water samples were contaminated by the total coliform in which the highest total colifrom was 1447.47 coliform $/ 100 \mathrm{ml}$ and the lowest coliform was 193.8 coliform $/ 100 \mathrm{ml}$ and this was also much higher than the present study. This difference can possibly be attributed to because of the time of the research conducted (seasonal variation and also by some environmental condition). In contrast, results of monitoring six sampling stations in the Geum River in Korea showed average concentrations of total coliforms ranging from 1670 to $8510 \mathrm{cfu} / 100 \mathrm{ml}$ (Geonha et al., 2005). That is higher than the present study and the possible reasons for this variation might be differences in dilution and sources of contaminants.

On the other hand, in Debrezeit town (Dasta, 2009) all water source samples $(100 \%)$ were contaminated by TC to the range of 1-4 coliform $/ 100 \mathrm{ml}$, but within the acceptable limit of $1-10$ coliform/100ml set by WHO (1997), as the research conducted in Bahir Dar (Genet, 2008) all water sources contaminated with $(100 \%) \mathrm{TC}$, with 35.5 coliform $/ 100 \mathrm{ml}$. In a similar study on rural hand-dug pump well water from South Wello, Atnafu (2006) reported that $50 \%$ of the 
Desalegn Amenu, Sissay Menkir \& Tesfaye Gobena

underground wells contain TC counts of $3.3 \mathrm{CFU} / 100 \mathrm{ml}$. This had lower range of total colifrom than present study, but the $(100 \%)$ of water samples contain total coliform.

\section{CONCLUSION}

The bacteriological results from this study showed that most of the bacteriological parameters measured (TC, FC, ) were not in harmony with the reference values set out by WHO, (2006) and they were grossly polluted. The contamination of these water sources with pathogenic organisms due to the absence of fencing of water sources that could prevent the entrance of animals, livestock grazing nearby water sources, people's open area defecation, collecting of water with unclean jug, cups ,agricultural activities nearby water sources, the lack of disinfection of the water reservoir, in some specially for unprotected well its difficulty to disinfect the water or treat the water sources before collecting the water.

It would be useful if the following important points are addressed: proper sanitary survey, design and implementation of water and/or sanitation projects; regular disinfections, maintenances and supervisions of water sources; and regular bacteriological assessment of all water sources for drinking in a planned manner.

\section{REFERENCES}

American Public Health Associations (APHA), (1998). Standard Methods for the Examination of Water and Waste Water. American People Health Association, $20^{\text {th }}$ edn, Washington DC.

Atnafu, M. (2006). Assessment of Bacteriological Quality of Drinking Water Supply at the sources and Point of Use at Home in Worebabu District, South Wollo. M.Sc Thesis. Addis Ababa University, Addis Ababa. 34-57.

Birhanu, M. (2008). Assessment of the contamination level of water and determines the major sources of contamination at water collection point in Yubdo Legebatu River, East Show, and Ethiopia. Addis Ababa. 34-65.

Cheesbrough, M. (1987). Medical laboratory manual for tropical countries, Butter-worth, Heine Mann, Oxford, II: 212-220.
Sci. Technol. Arts Res. J., Oct-Dec 2012, 1(4):33-37

Desta Kassa, (2009). Bacteriological and Physicochemical Quality assessment of Drinking Water Supply from source to taps in Debrezeit town, Ethiopia. Addis Ababa University, Addis Ababa.M.Sc.Thesis Addis Ababa University, Ethiopia 50-60.

Faris, K. and Kaba, M. (1999). Hygienic Behavior and Environmental condition in Jimma town, Southwestern Ethiopia, Ethiopian Journal of Health Development 13(2):77-86.

Federal Democratic Republic of Ethiopia, Ministry of Water Resources (FDRE, MWR) (2002). Ethiopian guidelines specification for drinking water quality. Federal Democratic Republic of Ethiopia, Ministry of Water Resorces, Addis Ababa, Ethiopia.

Geonha, K.T.C., Euiso and Dongryul, L. (2005). Diffuse and point pollution impacts on the pathogen indicator organism level in the Genum river, Korea. Science of the Total Environment 350:94-105.

Getnet Kassahun (2008). Physico-chemical and Bacteriological Drinking Water Quality Assessment of Bahir Dar town water supply from source to yard connection (North- Western Ethiopia). M.Sc Thesis, Addis Ababa University, Addis Ababa.

International Water and Sanitation Center (1989). Guidelines for Hygiene Education in Community Water Supply and sanitation. Occasional paper series 5.The Netherlands.

Mengesha Admassu., Mamo Wubshet \& Baye Gelaw (2004). A survey of bacteriological quality of drinking water in North Gondar. Ethiop Ethiopian Journal of Health Development 18(2):113-135.

Ministry of Health (MOH) (2007). Need Assessment to achieve Universal Access to Improved Sanitation and Hygiene, Unpublished Document, Addis Ababa, Ethiopia.

$\mathrm{MOH}$ (1997). Knowledge, attitude and practice of water supply, Environmental sanitation and hygiene practice in selected woredas of Ethiopia.

World Health Organization (WHO) \& UNICEF (2006). Meeting the MDG drinking water and sanitation target: the urban and rural challenge of the decade. Geneva.

World Health Organization (WHO) (2003). Guidelines for drinking water quality, Vol.3. World Health Organizations, Switzerland, Geneva.

World Health Organization (WHO) (2004). Water, sanitation and hygiene links to health, facts and figures. Geneva. 